\title{
DETERMINANTS OF CAPITAL FLIGHT IN PAKISTAN
}

\author{
Basheer Ahmad 1 \\ Qaim Din Sahto ${ }^{2}$ \\ Iqra University Islamabad, Pakistan
}

\begin{abstract}
Purpose: This study investigates the relationship between Capital Flight $(C F)$ and its Determinants: Foreign Direct Investment (FDI), External Debt (ED), Exchange Rate (ER), Foreign Reserves (FR), Gross Domestic Product (GDP) growth, and Inflation (I).

Methodology/Sample: CF from Pakistan is measured through the residual method which is the mostly used method in the literature. This method uses changes in ED, net FDI, Current Account Surplus (CAS) and changes in the FR to calculate the CF for the period of 1971 to 2011.

Findings: The results of the study show that there exist relationship between $C F$ and its determinants in the long run whereas no relationship is found in the short run.

Practical Implications: $C F$ refers to the condition when money, investment, funds and assets rapidly fly out of country due to economic and political events that discourage and cause individual investors and companies to lose their confidence in the host country and its economic and political conditions.
\end{abstract}

Keywords : CF; Gross Domestic Product; Inflation; Foreign Direct Investment; External Debt; Exchange Rate

\section{Jel Classification: D920, E220, F210}

\footnotetext{
* The material presented by the author does not necessarily portray the viewpoint of the editors and the management of the Institute of Business \& Technology (IBT)

* Basheer Ahmad : drbasheer@iqraisb.edu.pk

* Qaim Din Sahto 


\section{INTRODUCTION}

Returns and production can be increased by investing accumulated savings in different sectors of the economy. Investments in housing, health, and education are considered to be soft or social, while investments in transport, power, and water are considered to be infrastructural or hard. Infrastructural investments are purely economic in nature and are undertaken by private sector for private capital accumulation. Domestic savings, being the primary source of finance, has instigated the monetary authorities to promote it within the economy. This turns to an accumulated capital of a country and has the flexibility to freely flow among other countries over the years. During the 19th century, such capital flows, however, have become quite prominent.

A lot of countries, in the recent past, experienced a high level of $\mathrm{CF}$ and prone to more CF in future (Ndikumana \& Boyce, 2003), which is mainly due to the momentum generated by $\mathrm{CF}$. In most cases, the presence of high CF may cause private agents to expect higher rates for a given level of government spending, which decreases the tax base? Therefore, in such cases, the expected after-tax income declines, hindering domestic investment and leading private agents to seek higher returns abroad (Collier, Hoeffler, \& Pattillo, 2001). In addition, CF may be 'habit forming', so investors are likely to be lazy to respond any improvement in the investment environment. Pakistan is facing CF problem due to socio-economic and political conditions such as tax evasion, corruption, non-transparent privatization, black economy (Commissions from Government Projects and Hidden Contracts with Foreign Investors, Bribery etc). Another problem, which Pakistan is facing, is the political written off loans of more than Rs. 250 billion, which definitely flied to some other countries of the world especially to United Arab Emirate (UAE). In Pakistan, socio-economic and political change cause sizeable capital inflow and outflow. In the era of 1970 to 1973, which was the period of political and socio-economic turmoil, first the civil war and then the start of the new government along with its nationalization plans, sizeable capital out flow occurred. Sizeable capital flied due to governments nationalization policies, but in the era of Martial law private capital inflow and outflow coincide due to positive impression that economy would be privatized (Naqvi \& Sarmad, 1997). Furthermore, the period of 1977 to 1988 military governments which received huge aid from Untied States of America to support Pakistan play its role for winning the cold war against USSR. When democratic government came into power in 1988 it was assumed that the country will flourish and enjoyed its strong economic power but again a weak political government and limited period of democratic government after eleven years of Marshall law. The political situation was not supporting investment environment and reserves of the country came to the level US\$ 500 Million it was because of only loosing the confidence of local and foreign investors to fly out of country with foreign capital (UNCTAD, 2010).

Pakistan, since its role as front line state against terrorism, has been facing numerous socio-economic and political problems and CF is the major one. In 2000s capital flew from Pakistan to European Union, London Slumped Property Market, UAE in real estate, and other countries due to worsening law and order situations, unstable government 
policies, and weak multi political parties. All that discouraged local investors and foreign investors to invest in Pakistan. Pakistan was technically in debt default, investment climate (Local or Foreign) was non-existent, currency was depreciating its value against dollar and reduced private finance while the impact of terrorist activity, suicide attacks, counter-terror operations by the law enforcement and Pak Army, and trade miss invoicing were the major determinants which accelerated the flight of capital. It touched a peak in 2009-10. Over all result of this turmoil cost Pakistan a widespread poverty, large scale unemployment and unattractive investment environment in addition created problems for government to play its important role that lead to socio-economic problems for children, women and the poor (Group, 2012).

CF has major effect on the economy of Pakistan. Purpose of this study is to identify the significant determinants of CF in Pakistan. Low foreign reserves, non availability of manufacturing industry, social problems, low literacy rate, societal values and customs are considered to be major factors which effect the economic growth. Pakistan has been facing the problem of foreign exchange reserves that resulted in trade deficit and current account deficit problems. Pakistan is still struggling to play an independent role as a developed country in the list of third world country due to her deteriorating economic conditions. Pakistan is in dire need to come out of this economic crisis. With the help of handsome reserves Pakistan can prepare valued and independent polices for development of almost 200 million people of Pakistan and become a top country in South East Asian region.

\section{LITERATURE REVIEW}

High domestic investment reflects low CF and inflows of FDI should complement domestic capital. In earlier studies, domestic investment was not considered in relation to CF. CF has continuously unabated, in spite of continuous campaigns by governments for foreign investors to invest in the domestic economy. This raises a concern regarding the effect of CF on domestic investment. Pakistan specific studies on CF are very rare. $\mathrm{CF}$ is the result of variable government policies, political and economic conditions of country, weak government structure, trade miss invoicing, macro economic instability, lack of property rights protection, lack of savings, a complicated banking system, limited access to financial investment, high and unevenly enforced taxes, heavy unofficial activities, and high level of corruption (de Boyrie, Nelson, \& Pak, 2007; Mulino, 2002). Lower GDP growth, uneven corporate taxes; financial instability is the major determents of CF (Quazi, 2007). Impacts of CF and remittances in such a situation are macro-economic in stability, political instability, external debt, risk adjustment, and returns (Salisu, 2005; Vargo \& Lusch, 2004). The other determinants are current account deficit increases, exchange rate over valuation, inflation growth, budget deficits (AbdulRahman, Wang, Takim, \& Wong, 2011; Ajilore, 2010; Spilimbergo, Symansky, Cottarelli, $\&$ Blanchard, 2009). The main reasons include: a large public sector deficit, exchange rate misalignments, financial repression, inflation, economic slowdown, capital availability (revolving door), political instability, overvalued exchange rates, and rising tax rates (S. Ajayi, 1995; Hermes, Lensink, \& Murinde, 2002; Pastor Jr \& Wise, 1999). In general, CF from developing countries has been seen as symptoms of a "sick society". Some economists argue that CF cannot be recovered due to the debt problems of heavily 
indebted countries. Other comments on the natural, economic, and reasonable response, as a derogatory description of the portfolio selection, the affluent residents face some of the poor debtor countries (Lessard \& Williamson, 1987).

In 2004-05, foreign direct investment in Pakistan was US \$1.524 billion, more than the previous year's capital inflows to Pakistan. During 1991 to 2004-05, capital inflow of US was $\$ 9.089$ billion, out of which annual capital inflow to Pakistan was of US $\$ 649,270$, (Pakistan Economic Survey 2005-06). The capital inflow variables such as aid, foreign direct investment, and other forms of proxy have been used in many studies. Development assistance is used to finance CF. Long term debt inflows have shown significant effect on CF (Bauer, 1981). Capital inflows in form of foreign direct investment and aid to developing countries are an important reason for CF (S. Ajayi, 1995). Borrowing in public sector increases corruption due to foreign exchange supply. Anecdotal evidence suggests that about half of the amount of assistance to reach the intended beneficiaries, while other significant proportion of aid funds lost with the government agencies.

Debt trap, including domestic and foreign, is one of the major determinants of CF from Pakistan. It causes to increase the cost of debt servicing, raising interest and financial hardships to macroeconomic issues such as unemployment, reduced personal income, and high cost of living. During 2000 to 2007, drastic increase in external debt and debt service was observed in Pakistan. External debt was observed US \$3.2732 billion in 2000 , US\$33.567 billion in 2002, US\$ 35.581 billion in 2004, US\$ 36.111 billion in 2006, US $\$ 42.38$ billion in 2007, US\$ 53.71 billion in 2009, and US\$ 57.21 billion in 2010 (World Bank, World Development Indicators, 2011).

If current account deficit is understated, the CF estimate will be too high. The missing foreign exchange is, in fact, used to finance unrecorded imports. The net effect of trade miss invoicing can only be ascertained empirically. The studies which have considered this issue have found that trade miss invoicing is a significant net addition to total $\mathrm{CF}$ (M. S. I. Ajayi, 1997; Ndikumana \& Boyce, 2003). The results of this economic turmoil are large scale unemployment, widespread poverty, and burden of socio-economic problems which falls especially on women, children, and the poor community of Pakistan. There are sizeable investment opportunities in Pakistan, once multinational companies invest in Pakistan, they do not leave due to more profit and more investment opportunities expand their opportunities and operations. Almost 30,000 local and multinational companies are operating in Pakistan. Out of 30,000 companies 600 are multinational companies (World Investment Report and World Outlook, 2011). Foreign reserve increased to $\$ 16.4$ billion, trade deficit was at $\$ 13$ billion, revenue raised to $\$$ 13 billion, export increased to $\$ 18$ billion and Foreign Direct Investment was at $\$ 8.4$ billion during 2007, while the facts and figures were different in 2008 such as foreign exchange reserve decreased by $\$ 571.9$ million to $\$ 7749$ million. The foreign exchange reserve is decreased by $\$ 10$ billion to the rate of $\$ 6.59$ billion (State Bank of Pakistan, 2007-08). Foreign reserve during the 2010 stands at16.99billion (State Bank of Pakistan, 2010), domestic unstable economy, political uncertainty, fluctuating world demand for exports and impact of droughts on agricultural production leads to change in trade deficit and capital outflow from Pakistan. Pakistan has bilateral and multilateral trade 
agreements with national and multinational companies around the world due to member of World Trade Organization. Overvalued exchange rate is often found to be an important variable in the studies of $\mathrm{CF}$, its underlying determinants.

The fundamental economic concern about $\mathrm{CF}$ is its tendency to reduce welfare in the sense that it leads to a net loss in the total real resources available to an economy for investment and growth. That is, $\mathrm{CF}$ is viewed as a diversion of domestic savings away from financing domestic real investment and in favor of foreign financial investment.

\section{CONCEPTUAL FRAME WORK}

After going through the literature this study conceptualized different variables which are playing very important role to the CF. These variables have full power to effect countries economic growth and reasons decreased in foreign exchange reserves and are part of $\mathrm{CF}$. The conceptualized frame work has been designed as follows:

On the basis of above literature review and theoretical framework following hypothesis were formulated for empirical verification.

$\mathrm{H} 0$ : Long run relationship does not exist between $\mathrm{CF}$ and its determinants in the Pakistan economy.

H1: Long run relationship does exist between CF and its determinants in the Pakistan economy.

\section{METHODOLOGY}

Secondary data related to Foreign Direct Investment (FDI), External Debt (ED), Exchamge Rate (EXR), Foreign Reserve (FR), GDP Growth (GDPG), and Inflation (INF) is taken from the Workd Bank and State Bank of Pakitan website. To study impact of FDI, ED, EXR, FR, GDPG, and INF on CF (KF) have been used with their natural_logseries.

\subsection{Measurement of $\mathrm{CF}$}

In the general, following CF measurement techniques are discussed in the literature. Residual Method (1985), the Morgan Guaranty Method (1986), the Dooley Method (1986), the Hot Money Method (1986), the Trade Miss Invoicing Method (2002), and the Asset Method (Hermes et al., 2002). This study uses the Residual Method to calculate the CF from Pakistan.

World Bank (1985) measures CF indirectly by matching the source of capital inflows, i.e. net increase in external debt, net inflow of foreign investment, current account deficit, and foreign exchange reserves. CF can be expressed as:

$\mathrm{KF}_{\mathrm{R}}=\mathrm{ED}+\mathrm{nFDI}-\mathrm{CAD}-\mathrm{FR}$

$\mathrm{KF}_{\mathrm{R}}$ is CF based on the residual method, represents change, $\mathrm{ED}$ is the total stock of external debt reported by the World Bank or by International Monetary Fund, nFDI 
net foreign direct investment, CAD is the current account deficit, and FR the official foreign exchange reserves.

$\mathrm{CF}$ has been regressed on six matro-economic variables. $\Delta$ his relationship of exchange rate with economic fundamentals can be written in following equation: $\mathrm{KF}_{\mathrm{R}}=\beta_{0}+\beta_{1} * \mathrm{DED}+\beta_{2} * \mathrm{EXR}+\beta_{3} * \mathrm{~F} \Delta \mathrm{I}+\beta_{4} * \mathrm{FR}+\beta_{5} * \mathrm{INF}+\beta_{6} * \mathrm{GDPG}+\mathrm{e}$ After formal investigation of stationarity, Johansen's Cointegration technique and Granger Causality test were used to check the long run and short run relationship between $\mathrm{CF}$ and its determinants.

\section{RESULTS AND DISCUSSIONS}

Firstly, results of descriptive statistics have been presented for the seven variables of the study. Afterwards, the formal test of unit root existence, Augmented Dickey Fuller (ADF) test is used. Johansen's Cointegration and Granger causality tests were used to test the long run and short run relationship among CF and its determinants. Descriptive statistics related to all the seven variables are provided in Table-1.

\subsection{Results of ADF}

ADF statistics for all the variables are provided in Table-2. Almost all the variables have unit root at level and are stationary at first difference except FR and EXR.

\subsection{Results of Johansen's Cointegration}

Johansen Cointegration test results highlight the long-term relation of DED, nFDI, FR, GDPG, EXR, and INF with $\mathrm{KF}_{\mathrm{R}}$. Likelihood ratio statistics at $5 \%$ threshold that $\mathrm{KF}_{\mathrm{R}}$ has a long run relationship with its determinants during the sample period and there exist three cointegration equations in the system (See Table3).

\subsection{Results of Granger Causality}

None of the determinants of $\mathrm{KF}_{\mathrm{R}}$ Granger cause $\mathrm{KF}_{\mathrm{R}}$ and vice versa. This indicates that there does not exist any short term relationship between $\mathrm{KF}_{\mathrm{R}}$ and its determinants (See Table 4).

\subsection{Results of Regression Equation}

Unit root investigation, however, reported that all variables used in study contain unit root at level and are integrated at first difference. Later results of Johansen's cointegration revealed that variables are cointegrated, therefore, regression is run at level (See Table 5).

\section{CONCLUSION AND RECOMMENDATIONS}

This study has explored the relationship between $\mathrm{KF}_{\mathrm{R}}$ and its' determinants except EXR. Several arguments have been discussed to illustrate the importance of KF in Pakistan. The most important determinant is $\mathrm{nFDI} . \mathrm{KF}_{\mathrm{R}}$ is extremely effected by high nFDIs. FR is the only determinant which helps to bring down the $\mathrm{KF}_{\mathrm{R}}$. Pakistan need high FR to control the $\mathrm{KF}_{\mathrm{R}}$. As EXR is not effecting $\mathrm{KF}_{\mathrm{R}}$ so there is no need to drop the value of Pakistani Currency to control the $\mathrm{KF}_{\mathrm{R}}$. 


\section{ACKNOWLEDGEMENT}

First of all with a profound gratitude, we are thankful to Almighty Allah forgiving us success, knowledge and understanding without which we would not been capable of completing this research paper.

We are also profoundly grateful to all our family members whose endurance and understanding have played a significant role in our success by sacrificing the important family time and supporting us all over the research work.

We are finally thankful to the editor, reviewers and IBT specially who provided us with the opportunity to publish our research paper in this esteemed journal.

\section{REFERENCES}

Abdul-Rahman, H., Wang, C., Takim, R., \& Wong, S. (2011). Project schedule influenced by financial issues: Evidence in construction industry. Scientific Research and Essays, 6(1), 205-212.

Ajayi, M. S. I. (1997). An Analysis of External Debt and CF in the Severely Indebted Low Income Countries in Sub-Saharan Africa (EPub): International Monetary Fund.

Ajayi, S. (1995). CF and external debt in Nigeria.

Ajilore, T. O. (2010). An economic analysis of CF from Nigeria. International Journal of Economics and Finance, 2(4), p89.

Bauer, P. T. (1981). Equality, the third world, and economic delusion: Harvard University Press.

Collier, P., Hoeffler, A., \& Pattillo, C. (2001). Flight capital as a portfolio choice. the world bank economic review, 15(1), 55-80.

De Boyrie, M. E., Nelson, J. A., \& Pak, S. J. (2007). Capital movement through trade misinvoicing: the case of Africa. Journal of Financial Crime, 14(4), 474489.

Group, W. B. (2012). World Development Indicators 2012: World Bank Publications.

Hermes, N., Lensink, R., \& Murinde, V. (2002). Flight capital and its reversal for development financing: WIDER Discussion Papers//World Institute for Development Economics (UNU-WIDER).

Lessard, D. R., \& Williamson, J. (1987). CF and the third world debt. Mulino, M. (2002). On the determinants of CF from Russia. Atlantic Economic Journal, 30(2), 148-169.

Naqvi, S. N. H., \& Sarmad, K. (1997). External Shocks and Domestic Adjustment: Pakistan's Case, 1970-1990: Oxford University Press, USA.

Ndikumana, L., \& Boyce, J. K. (2003). Public debts and private assets: explaining CF from Sub-Saharan African countries. World Development, 31(1), 107-130.

Pastor Jr, M., \& Wise, C. (1999). Stabilization and its Discontents: Argentina's Economic Restructuring in the 1990s. World Development, 27(3), 477-503.

Quazi, R. (2007). Economic freedom and foreign direct investment in East Asia. Journal of the Asia Pacific Economy, 12(3), 329-344.

Salisu, M. (2005). The Role of CF and Remittances in Current Account Sustainability in Sub-Saharan Africa. African Development Review, 17(3), 382-404. 
Spilimbergo, M. A., Symansky, M. S. A., Cottarelli, M. C., \& Blanchard, O. J. (2009). Fiscal policy for the crisis: International Monetary Fund.

UNCTAD, V. (2010). World Investment Report, 2011 et 2012, et UNCTAD. World I investment Prospects Survey, 12.

Vargo, S. L., \& Lusch, R. F. (2004). Evolving to a new dominant logic for marketing. Journal of marketing, 68(1), 1-17. 


\section{APPENDIX}

Figure 1 Conceptual Framework

- Foreign Direct Investment
- ExternalDebt
- Forehange Rate
- Gross Domestic Product
- Growth
- Inflation

\section{Capital Flight}

Table-1: Descriptive statistics for study variables

\begin{tabular}{|c|c|c|c|c|c|c|c|}
\hline & $\boldsymbol{K F}$ & $\boldsymbol{D E D}$ & $\boldsymbol{n F D I}$ & $\boldsymbol{F R}$ & $\boldsymbol{G D P G}$ & $\boldsymbol{E X} \boldsymbol{R}$ & $\boldsymbol{I N F}$ \\
\hline Mean & 16.63 & 14.93 & 18.33 & 21.01 & 4.84 & 33.13 & 9.45 \\
\hline Median & 21.64 & 20.80 & 19.37 & 20.69 & 4.85 & 23.80 & 8.27 \\
\hline Maximum & 24.29 & 22.74 & 22.44 & 23.40 & 10.22 & 86.34 & 26.66 \\
\hline Minimum & -22.44 & -21.57 & -15.20 & 18.68 & 0.47 & 4.76 & 2.91 \\
\hline Std. Dev. & 14.40 & 14.76 & 5.71 & 1.39 & 2.26 & 24.57 & 5.42 \\
\hline
\end{tabular}

Table-2: Results of Unit Root Investigation

\begin{tabular}{|c|c|c|c|c|c|}
\hline Variable & Test for Unit Root & Test Stat & $1 \%$ Critical Values & $5 \%$ Critical Values & Conclusion \\
\hline \multirow{2}{*}{$K F_{R}$} & At Level & -3.23819 & -4.205 & -3.52661 & \multirow{2}{*}{$\mathrm{I}(1)$} \\
\hline & At $1^{\text {st }}$ Difference & -7.55544 & -4.21187 & -3.52976 & \\
\hline \multirow{2}{*}{$D E D$} & At Level & -5.5827 & -4.21187 & -3.52976 & \multirow{2}{*}{$\mathrm{I}(0), \mathrm{I}(1)$} \\
\hline & At $1^{\text {st }}$ Difference & -7.24927 & -4.22682 & -3.5366 & \\
\hline \multirow{2}{*}{$n F D I$} & At Level & -2.27535 & -4.22682 & -3.5366 & \multirow{2}{*}{$\mathrm{I}(1)$} \\
\hline & At $1^{\text {st }}$ Difference & -10.6005 & -4.21187 & -3.52976 & \\
\hline \multirow{2}{*}{$F R$} & At Level & -2.42967 & -4.205 & -3.52661 & \multirow{2}{*}{$\mathrm{I}(1)$} \\
\hline & At $1^{\text {st }}$ Difference & -6.30413 & -4.21187 & -3.52976 & \\
\hline \multirow{2}{*}{$G D P G$} & At Level & -4.98128 & -4.205 & -3.52661 & \multirow{2}{*}{$\mathrm{I}(0), \mathrm{I}(1)$} \\
\hline & At $1^{\text {st }}$ Difference & -10.3178 & -4.21187 & -3.52976 & \\
\hline \multirow{2}{*}{$E X R$} & At Level & -2.94417 & -4.27328 & -3.55776 & \multirow{2}{*}{$\mathrm{I}(1)$} \\
\hline & At $1^{\text {st }}$ Difference & -4.67834 & -4.21913 & -3.53308 & \\
\hline \multirow{2}{*}{$I N F$} & At Level & -3.21086 & -4.205 & -3.52661 & \multirow{2}{*}{$\mathrm{I}(1)$} \\
\hline & At $1^{\text {st }}$ Difference & -6.08363 & -4.21187 & -3.52976 & \\
\hline
\end{tabular}


Table-3: Cointegration Results

\begin{tabular}{|c|c|c|c|}
\hline Eigen value & LR Stat & $\mathbf{5 \% ~ C V}$ & No. of CE(s) \\
\hline 0.806887 & 189.0524 & 134.678 & None * \\
\hline 0.675269 & 124.9177 & 103.8473 & At most $1 *$ \\
\hline 0.515349 & 81.05212 & 76.97277 & At most $2 *$ \\
\hline 0.412114 & 52.80339 & 54.07904 & At most 3 \\
\hline 0.325329 & 32.08574 & 35.19275 & At most 4 \\
\hline 0.264168 & 16.73806 & 20.26184 & At most 5 \\
\hline 0.11523 & 4.774669 & 9.164546 & At most 6 \\
\hline
\end{tabular}

Table-4: Results of Granger Causality Test between CF and its Determinants

\begin{tabular}{|c|c|c|c|}
\hline Null Hypothesis: & Obs & F-Statistic & Prob. \\
\hline DED does not Granger Cause KF & 39 & 0.60288 & 0.553 \\
\hline KF does not Granger Cause DED & & 2.22981 & 0.123 \\
\hline NFDI does not Granger Cause KF & 39 & 0.05174 & 0.9496 \\
\hline KF does not Granger Cause NFDI & & 0.15866 & 0.8539 \\
\hline FR does not Granger Cause KF & 39 & 0.26813 & 0.7664 \\
\hline KF does not Granger Cause FR & & 0.55074 & 0.5816 \\
\hline GDPG does not Granger Cause KF & 39 & 0.35122 & 0.7064 \\
\hline KF does not Granger Cause GDPG & & 2.3223 & 0.1134 \\
\hline EXR does not Granger Cause KF & 39 & 1.06679 & 0.3553 \\
\hline KF does not Granger Cause EXR & & 3.2052 & 0.0531 \\
\hline INF does not Granger Cause KF & 39 & 0.8743 & 0.4263 \\
\hline KF does not Granger Cause INF & & 1.15983 & 0.3256 \\
\hline
\end{tabular}

Table-5: Results of Regression

\begin{tabular}{|c|c|c|c|c|c|c|c|}
\hline Variable & $n F D I$ & $I N F$ & $G D P G$ & $F R$ & $E X R$ & $D E D$ & C \\
\hline Coefficient & 0.652111 & 1.153325 & 1.314446 & -6.30467 & 0.194306 & 0.199941 & 110.4631 \\
\hline Std. Error & 0.43025 & 0.415983 & 1.07541 & 3.846947 & 0.230064 & 0.145851 & 71.74033 \\
\hline t-Statistic & 1.515657 & 2.772528 & 1.222274 & -1.63888 & 0.844574 & 1.370855 & 1.539762 \\
\hline \multicolumn{2}{|c|}{ R-squared } & \multicolumn{2}{|c|}{0.520152} & \multicolumn{3}{|c|}{ Adjusted R-squared } & 0.435473 \\
\hline \multicolumn{2}{|c|}{ F-statistic } & \multicolumn{2}{|c|}{2.668527} & \multicolumn{3}{|c|}{ Prob(F-statistic) } & 0.031324 \\
\hline
\end{tabular}

